\title{
The Legitimacy of Military Intervention in Yemen and Its Impacts
}

\author{
Junxiang Mao ${ }^{*}$, Ammar Ahmad Ahmad Gady ${ }^{*}$ \\ ${ }^{1}$ Human Rights Center, Vice-Dean, Law School, Central South University, Changsha, China \\ ${ }^{2}$ International Law-Human Rights, Law School, Central South University, Changsha, China \\ Email: tangmao200304@sina.com,160308003@csu.edu.cn
}

How to cite this paper: Mao, J. X., \& Gady, A. A. A. (2021). The Legitimacy of Military Intervention in Yemen and Its Impacts. Beijing Law Review, 12, 560-592. https://doi.org/10.4236/blr.2021.122030

Received: March 19, 2021

Accepted: June 1, 2021

Published: June 4, 2021

Copyright (C) 2021 by author(s) and Scientific Research Publishing Inc. This work is licensed under the Creative Commons Attribution International License (CC BY 4.0).

http://creativecommons.org/licenses/by/4.0/ (c) (i) Open Access

\begin{abstract}
Recently, some Arab governments, including Yemen, have requested other states to intervene militarily to eliminate the protests and popular movements that challenge their powers under the justifications for consensual interventions, resulting in the emergence of armed civil conflicts many violations of human rights. This type of interference contradicts the provisions of the United Nations Charter and other international conventions that prohibit military force in international relations. However, this interference almost becomes recognized by states without any opposition. For more than six years, no initiatives have been made to resolve the dispute between the parties involved in Yemen's war because Yemen is considered less strategically important for the permanent members' interests than Saudi Arabia. As with other problems and humanitarian crises (Syria and Libya), the UNSC member states tend to leave Yemen's diplomatic initiatives to the Special Envoy of the Secretary-General.
\end{abstract}

\section{Keywords}

UN Security Council, Consensual Intervention, The Arab Coalition, Human Rights Violations, Yemen

\section{Introduction}

\subsection{Purpose}

The United Nations Charter (UN Charter) was formally drafted to prevent member states from attempting to use force against another state's territorial integrity or political freedom within their international relations. Non-international conflicts

*Equally contributed to this work. 
(civil wars) escalated in some countries during and after the Cold War. As a result, opportunities increased for foreign intervention in the internal affairs of states directly through the use of force or indirectly through material and logistical support for local people under a legal cover (e.g. removal of threats to international stability and the interests of states). Regional wars broke out in some Arab countries, starting with Iraq's invasion of Kuwait in 1991. The invasion led to the escalation of international options to use force to enforce the United $\mathrm{Na}$ tions Security Council (UNSC) resolution and ended with the overthrow of Iraq's government in 2003. Events recently started with the so-called anti-government demonstrations (the Arab Spring) in response to authoritarian regimes and a low standard of living. Such demonstrations led to the overthrow of some Arab governments such as those in Tunisia, Egypt, Libya, Syria and Yemen. The international community's positions on these protests are on opposite ends of the spectrum. On the one hand some directly support the use of force to overthrow governments under the justification of protecting the human rights of protestors (e.g. French-led international military coalition against the Libyan regime). This stance recognises protesters as legitimate representatives. Moreover, some allies indirectly support demonstrators through political, military and logistical aid (e.g. supporting America and Turkey and some Arab countries in demonstrating against the Syrian regime). On the other hand, some Arab governments have called on foreign states to intervene directly by using force to defend their legitimacy and internal peace. For example, Syria called on Russia and Iran to intervene directly in the uprisings. Hence, the Arab coalition, led by Saudi Arabia, made a forceful intervention in Yemen to maintain the outgoing legitimacy. On the basis of these incidents, several questions arise. What are the exceptions that States can use military force in the perspective of the UN Charter and international conventions? Will the consensual intervention obtain the international legal status that leads to the continuation of armed conflicts? What is the legal framework for the intervention and use of military force in Yemen? What are the reasons for prolonging the war in Yemen, which has led to persistent human rights violations? This article attempts to discuss the intervention and use of military force in Yemen. Section 1 presents the background on the rationale for military interventions. Section 2 clarifies the Arab military intervention and its motivations in Yemen. Section 3 discusses the UNSC's inability to evolve as an international authority in authoritative conflict resolution procedures by peaceful means in keeping with the purposes and principles of the UN. Section 4 clarifies the effects of foreign intervention on human rights in Yemen.

\subsection{Background and Methodology}

The establishment of the UN and the adoption of its Charter in 1945 is a turning point for the circumstances surrounding the two World Wars. The Charter's preamble explicitly declares that the member states work together to save the next generations from the scourge of war and to work towards the development 
of friendly relationships among states on the basis of respect for the principle of equal rights and self-determination (U.N. Charter article 1) ${ }^{1}$. Therefore, all member states are advised to refrain from the use of force in their international relations, which is contrary to the territorial integrity or political independence of the state. An exception is the UNSC, which has been granted authority to use force under Chapter VII of the UN Charter. In the aftermath of the Cold War, foreign relations have developed and changed, whether in terms of the framework of the international system or international actors. The developments are the result of emerging new challenges, such as new biological weapons, terrorism and extremism, which often come from non-international actors and beyond the territorial borders of states. These challenges have led to the expansion of the concept of security and state interest by establishing military alliances, security agreements and entering into security partnerships. Such measures aim to protect state security and share responsibilities with other states to jointly resolve security threats. In addition to the evolution of international conflicts between states to internal conflicts within states in the form of separatist movements, civil wars, which posed a challenge to international peace and security, have contributed to expanding opportunities for foreign interventions to protect the international peace and internal security of states. Nevertheless, scholars provided analyses and comments on military interventions. Some of them opposed interference in domestic affairs either for humanitarian or self-defence purposes. For instance, Wippma (1996a: p. 670) explained that "[t]he Council remains extremely reluctant to authorize intervention against the will of a sitting government or to rely on humanitarian motives as the basis for installing a particular government or defeating a particular party to an internal conflict". Symes (1997: p. 593) argued " $[\mathrm{t}] \mathrm{he}$ respects for the territorial and political sovereignty of States is a key feature of the international legal order. The natural and inevitable corollary of this respect for sovereignty is the international legal prohibition on interference by a nation in the sovereign territory or affairs of another". Thomas (2003: p. 17) expressed concern that "[a] standing or threatened policy of humanitarian intervention by the United States and the West then becomes the cause of human rights nightmares". Pattison (2010: p. 57) criticised the humanitarian intervention: " $[t]$ he states use humanitarian intervention as a cover to engage in abusive humanitarian intervention. Consequently, we should use an intervener's legal status to decide who should intervene because this avoids abusive humanitarian intervention". Nonetheless, some scholars advocated such interventions for humanitarian or self-defence reasons whether on legitimate grounds or not. For instance, Ken Booth argued that " $[\mathrm{t}]$ he use of force is a particularly troubling issue for those with cosmopolitan sensibilities, for it throws into sharp relief the tension between the aim of delegitimizing political violence and the desire to stop massive human rights abuses in conditions where there seems to be no alternative to military intervention". Boerefijn and Flinterman (2008: p. 57) con-

${ }^{1} \mathrm{U}$. N. Charter art.1, par.2. 
firmed that " $[t]$ he gross human rights violations may lead to international sanctions against the state concerned, even if the victims happen to be citizens of that same state. In so far concerned, the old principle of non-intervention in the internal affairs of a state has retreated". de Tangle (2015: p. 119) explained that international responsibility arises "[w]hen a State has incurred in an internationally wrongful act; i.e., conduct consisting of an action or omission that is attributable to a State under International Law and constitutes a breach of the State's international obligation".

In general, legal scholars may think that the adoption of force or of material and logistical support from foreign direct intervention options is a war necessary under legitimate justifications for maintaining international peace in compliance with the UN Charter. However, recent events have shown how long interventions will last, as those interventions are likely to be completed in direct negotiations between parties of conflicts, such as the negotiations between the US and Taliban Afghanistan. Moreover, the results of these interventions are likely to be incorrect as former British prime minister Tony Blair said in the case of intervention of Iraq. Hence, restoring peace in a state is difficult, especially after many serious violations of human rights. This article aims to highlight the reasons for military interventions and their effect on Yemen's human rights from an alternative solution perspective and applies an alternative method of solution on this topic, where the UN and UNSC have the primary task of prohibiting member states from using military force in their international affairs as well as defending the rights and dignity of citizens. The authors strongly believe that decisions to use force have a serious negative effect on people's rights and dignity. Foreign direct intervention has significant consequences on individuals of the state whose sovereignty has been violated. Evidence has also shown that military interventions have led to human rights abuses and many civil wars. States that decided to intervene have sought to escape their responsibility to the international community and the individuals of the State, and they justify their intervention on the basis of consensual intervention or preservation of international peace. For example, military and non-military interventions in some Arab countries, including Yemen, have resulted in civil wars and major violations of human rights, as well as a rise in the number of refugees under different justifications. This article discusses: the legal framework from the point of international law for the intervention and use of military force in Yemen and the reasons for prolonging the war.

\section{Background on the Rationale for Military Intervention}

Some legal rules may have an exception. These exceptions cannot be resorted to unless the conditions for the application arise. In addition, the rule of tolerance and peace in international relations (the right of sovereignty) has exceptions. This chapter gives an overview of the legal rule on the use of military force and its exceptions. 


\subsection{State Sovereignty}

In domestic law, state sovereignty is an entity with political authority and organisation for society, to administer different authorities with specific legislative, executive and judicial powers. In the term international community, each state's sovereignty participates in international relations on the basis of sovereign equality. In international legal order, sovereignty is a component of an international personality that requires an independent public authority recognised by other states. Maftei (2015: p. 55) identified "the sovereignty is a feature of states; it represents the rule of law and independence of state authority in expressing and achieving the governors' will as general will, which is compulsory for the whole society". According to Stephen (1999: p. 5), sovereignty can be classified into two types; International sovereignty refers to a political system based on the exclusion of external actors from interference within a given territory. National sovereignty refers to the formal organisation of political authority within the state and the ability to exercise its authority within the boundaries of its political system. Reisman (1990: p. 867) explained "This type of sovereignty involves authority and control. By the end of the Second World War, national sovereignty became the sovereignty of the people (popular sovereignty), which was firmly rooted as one of the fundamental assumptions of political legitimacy". The concept of popular will is the theoretical and practical source of political authority and all legislations. Most democratic governments and republican authorities affirm this concept in their constitutional laws (e.g. US Constitution'2, France's Constitution $^{3}$, and the UK constitution ${ }^{4}$ ). To uphold popular will, Article 1 of the UN Charter established one of the purposes of the UN in developing friendly relations among states "based on respect for the principles of equal rights and self-determination of peoples". Subsequently, self-determination is an appraisal of internal authority of governments in the international context. Article 21(3) of the Universal Declaration of Human Rights stated about customary international law that " $t \mathrm{t}$ ] he will of the people shall be the basis of the authority of government; this will shall be expressed in periodic and genuine elections which shall be by universal and equal suffrage and shall be held by secret vote or by equivalent free voting procedures"5. As a rule, international relations are governed by the absolute sovereignty of states to exercise their internal affairs in accordance with the principle of sovereign equality. Article 2(1) of the UN Charter declared that "[ $[\mathrm{t}] \mathrm{he}$ Organisation is based on the principle of the sovereign equality of all its Members". Furthermore, the UN Charter encouraged all members to settle their international disputes by peaceful means and reject any foreign interference that could affect popular sovereignty. This prohibition was created in response to the human rights violations because of the failure of the

${ }^{2}$ U.S. Constitution. Preamble.

${ }^{3}$ Article (3) France's Constitution of 1958.

${ }^{4}$ Article (1) Constitution of the United Kingdom of Great Britain and Northern Ireland.

${ }^{5}$ UN General Assembly, Universal declaration of human rights, 302 UN General Assembly (1948). 
League of Nations and the outbreak of the Second World War. Hence, the prohibition of the use of force in international relations among states became the most important purpose and principle of the UN. Article 2 (4) of the UN Charter (1948) explicitly stated that "[a]ll Members shall refrain in their international relations from the threat or use of force against the territorial integrity or political independence of any state, or in any other manner inconsistent with the Purposes of the United Nations". This article was reinforced in many UNGA resolutions. For example, the UNGA resolution on Declaration on the Inadmissibility of Intervention in the Domestic Affairs of States and the Protection of their Independence and Sovereignty confirmed that "[n]o State has the right to intervene, directly or indirectly, for any reason whatever, in the internal or external affairs of any State. Consequently, armed intervention and all other forms of interference or attempted threats against the personality of the State or against its political, economic and cultural elements, are condemned"6. An identical provision was stipulated in the Declaration on Principles of International Law concerning Friendly Relations and Cooperation among States in accordance with the UN Charter ${ }^{7}$, and by the Declaration on the Enhancement of the Effectiveness of the Principle of Refraining from the Threat or Use of Force in International Relations ${ }^{8}$. This ban has also confirmed in all controversial cases by the International Court of Justice (ICJ), such as Nicaragua v. United States (1986), Oil Platforms Case (2003) and Armed Activities on the Territory of the Congo (2005). In these cases, the court found a violation of Article 2 (4) and a violation of the sovereignty of the affected state.

\subsection{Legitimacy of the Use of Military Force}

According to the traditional concept of international relations and international law, sovereignty is absolute without exception. Therefore, the scrutiny of international human rights without the permission of the sovereign could arguably constitute a violation of sovereignty ${ }^{9}$. This term (state sovereignty) remains recognised theoretically and practically in international law. Nevertheless, modern international law protects sovereignty (popular sovereignty rather than state sovereignty) with changes in the manner of protection through exceptions on the recourse to the use of force in accordance with the purposes of the UN Charter.

\subsubsection{The UN Security Council}

In addition to the general prohibition in Article 2(4), the UN Charter stated that the Charter does not authorise the UN to interfere in the matters of states, which are essentially within domestic jurisdiction. The exceptions are the enforcement measures adopted by the UNSC (U.N. Charter article 2). The Charter attempted to radically change international law in terms of the use of force. The authority

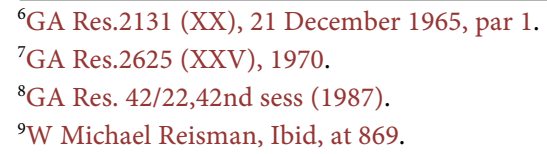


to determine the existence of any threat to peace, breach of peace, or act of aggression and the decision on what measures should be taken to maintain international peace and security are vested on the UNSC. Nevertheless, the UNSC limits the use or threat of use of force without resorting to UNSC resolutions and attempts to fashion a structure to settle disputes without recourse to force (Keely, 1995). The UNSC can recommend measures not involving the use of force, such as complete or partial interruption of economic relations and/or rail, sea, air, postal, telegraphic, radio and other means of communication and the severance of diplomatic relations. However, if the UNSC considers that the previous measures would be inadequate or have proven to be inadequate, Chapter VII specified the powers of the UNSC to authorise member states to use force to enforce its resolutions in certain circumstances. Article 42 gives the Council the authority to " $\mathrm{t}]$ ake another action by air, sea, or land forces as may be necessary to maintain or restore international peace and security. Such action may include demonstrations, blockade, and other operations by air, sea, or land forces of Members of the United Nations". The justification for the use of force authorised by the UNSC varies in different situations that constitute a threat to international peace under Chapter VII of the Charter. For instance, the UNSC authorised the use of force to redress situations, such as the cases in Korea (SC Res. 85, 1950), and the Iraqi invasion of Kuwait (SC Res. 678, 1990). The UNSC also authorised the use of force to peace enforcement, such as the intervention in Somalia (SC Res. 794, 1992), and East Timor (SC Res. 1264, 1999).

\subsubsection{The Right to Self-Defence}

States have an inherent right to use force to defend their countries. The UN Charter declared the right to self-defence as the only exception to the prohibition of the use of force in international relations. The Charter did not abolish this right that existed earlier in customary international law, where it preserved the right of states to self-defence. Article 51 affirms that "[n]othing in the present Charter shall impair the inherent right of individual or collective self-defence if an armed attack occurs against a Member of the United Nations, until the Security Council has taken measures necessary to maintain international peace and security". Thus, an armed attack must take place before states can exercise their right to self-defence, and if this exercise is carried out, it should be exercised until UNSC has taken the necessary measures to maintain international peace and security. Actions taken by any member in the exercise of the right to self-defence must be reported to the Council immediately. These measures should not in any way affect the authority and responsibility of the Council. The ICJ takes the position that an armed attack is a prerequisite for the lawful exercise of self-defence in all contentious cases. For instance, in the case of Nicaragua, the ICJ stated that "[i]n the case of individual self-defence, the exercise of this right is subject to the State concerned having been the victim of an armed attack" (ICJ Report, 1986). The Court also stressed the prerequisite of an armed attack in the oil platforms case: "[i]n order to establish that it was legally 
justified in attacking the Iranian platforms in exercise of the right of self-defence, the United States has to show that attacks had been made upon it for which Iran was responsible; and that those attacks were of such a nature as to be qualified as "armed attacks" within the meaning of that expression in Article 51 of the United Nations Charter, and as understood in customary international law on the use of force" (ICJ Case, 2003). Article 51 of the Charter used the term "real armed attack" to describe the status of this right. Conversely, the use of force without an armed attack constitutes an unlawful exercise of the right to self-defence. Therefore, what justifies the use of force for anticipatory self-defence and preventive self-defence, in which the difference between the two is an imminent armed attack? A Green (2009: p. 28) explained that "[a]n anticipatory self-defence; is employed to refer to action taken in response to an imminent threat. Preventive self-defence; is used to denote action taken in response to a perceived threat that is more temporally remote". Most scholars believe that the use of these measures under the preventive self-defence rationale is unlawful. This stance is confirmed by the statement of the ICJ on the Nicaragua case and the Democratic Republic of the Congo v. Uganda case: "[a]rticle 51 of the Charter may justify the use of force in self-defence only within the strict confines there laid down. It does not allow the use of force by a state to protect perceived security interests beyond these parameters. Other means are available to a concerned state, including, in particular, recourse to the Security Council” (ICJ Case, 2005). Notwithstanding, scholars differed on the legality of the use of force under the justification of anticipatory self-defence (Ian Brownlie, 1980). Some of them claim that although international customary law permits the use of the right to self-defence, it allows only a narrow right to self-defence. States cannot be permitted to use force under the justification of anticipatory self-defence. Hence, the drafters of the Charter have taken steps towards regulating the use of force by imposing restrictions on the exercise of the right to self-defence, as confirmed by summary record 1627 of the meeting of the Committee on International Law: "[i]n formulating Article 51 the authors of the Charter had taken an immense step towards pacifism by taking care to restrict the exercise of the right of self-defence to one clear-cut case" ${ }^{10}$. These scholars tend to take the view that the purpose of the UN Charter prohibits the use of force between states. Moreover, this article is an exception to the general prohibition of the use of force. This exception should be interpreted restrictively as prohibiting anticipatory action (Abi-Saab, 1987). However, unlike anticipatory action, an interceptive strike is legal under Article 51 because an armed attack has occurred (Tom Ruys, 2010). Some scholars tend to justify anticipatory action in self-defence against an imminent threat as the purpose of Article 51, which is to preserve the customary understanding of the right, as prescribed by the Caroline criteria (Mcdougal \& Florentino, 1961). Nonetheless, this article did not show any restriction of selfdefence in cases where an armed attack had already occurred. In addition, scholars

${ }^{10}$ GA CN.4/SR.1627, para3. 
argue that new developments and new threats need anticipatory self-defence action as soon as the threat of an attack is imminent, especially when no other means can stop it (Malanczuk, 1987). For instance, the UN high-level panel concluded its report on international security issues by stating that "a threatened State, according to long-established international law, can take military action as long as the threatened attack is imminent, no other means would deflect it and the action is proportionate"11. The British International Lawyers Committee affirmed this position by endorsing the principles of international law on the use of force by states in self-defence, as the right of states to act in self-defence to avoid the threat of an imminent attack was widely accepted. Hence, the assumption that self-defending states would always wait for an armed attack was unrealistic (Wilmshurst, 2006). In all cases, scholars affirm the strict conditions for the application of this right: that danger (the occurrence or possibility of an attack) is certain and it could not be avoided by other means due to the limited time. Additionally, this action should also be restricted in the use of force, which is necessary to prevent an attack (Bori Szabo, 2011).

\section{Military Intervention in Yemen}

The outbreak of political disorder (the Arab Spring) led to the emergence of civil wars in some Arab countries (e.g. Syria, Libya and Yemen). These Arab countries gained the support of some foreign states, either directly through military interventions or indirectly through financial and logistical support. Such interventions led to the emergence of numerous abuses of human rights. The positions of the international community (UNGA, UNSC) differed between support or condemnation of these wars. This chapter highlights the military intervention in Yemen and the motives behind it.

\subsection{Overview of the Current Conflict}

Political disorders in Yemen led to the overthrow of the former Yemeni president's government. The event followed the signing of an agreement to transfer the presidency to the vice president and to grant him the duty to run the country for two years only. Later, one of the competing elements in Yemen overthrew the vice resident, which compelled some Arab states to use their military to interfere directly. This part provides a summary of the worsening political situation in Yemen and its implications.

\subsubsection{Overview of the Crisis}

During the six wars between the government forces (supported by the Muslim Brotherhood, Saudi Arabia) and the Houthi movement from 2004-2009, problems in Yemen began to worsen. Wars resulted in harmed civilians. The problems became more dangerous and complicated in November 2009 during the sixth war, when Saudi Arabia openly intervened. The government of Saudi Ara-

${ }^{11}$ UN High-Level Panel (2004) Para 188, at 54. 
bia responded to Houthi incursions and launched a major military operation on its southern border, which for decades was the first unilateral Saudi military force in Yemen. In 2010, the southern movement began in Southern Yemen. It was backed by the United Arab Emirates (UAE), which demanded the separation of Southern Yemen and the establishment of an independent state, owing to the demand of most retirement workers to change their living standards or return them to service. This demand further complicated the situation politically. Eventually, the outbreak of the political disorder led to the overthrow of some Arab governments including Yemen. Peaceful demonstrations broke out against the former president who ruled Yemen for 33 years. Youth groups opposed his authority with accession by other opposition political parties, such as the Muslim Brotherhood, the Houthi movement and the Southern separatist movement (Joint Meeting Parties and their Partners). Through the initiative of the Gulf Cooperation Council (GCC), all political parties in Yemen reached an agreement on the former president's abdication of his authority, which was transferred to the vice president ${ }^{12}$. Under this agreement, the transition of authority was regulated and prevented the civil war. The former president handed over his authority to the vice president through an election. The vice president was the only candidate and won more than 99\% of the votes in the February 2012 (Roland Popp, 2015). The vice president was entrusted with the task of administering the country for two years and establishing a national unity government headed by opposition parties. Additionally, the vice president was tasked with convening a comprehensive National Dialog Conference for all powers and political actors, including youth groups, members of civil society and women, to decide the future of Yemeni politics. Contrary to the agreement, the most important supporters of the revolutionary movement (civil society activists and youth groups) were not involved in establishing the government. The new government was formed from the two major parties in Yemen (the General People's Congress and its allies, Joint Meeting Parties their partners). Throughout the transitional era, several changes took place in the shape of the State. For example, the army was restructured and the Muslim Brotherhood won most positions in the State. With the support of some states in the region and some developed states, the structure of the state was proposed to be changed from a unified state to a federal state, where Yemen is divided into six major regions. This proposal was rejected by the Houthi movement and the Southern separatist movement (Roland Popp, 2015). On August 20, 2014 and after the assassination of their representatives at the comprehensive National Dialog Conference, the Houthi movement began mobilising its supporters to overthrow the government. In February 2015, after the negotiations between all political parties, the Peace and National Partnership Agreement and its security annex were signed. The signatories agreed to form a new government that involves all political parties. However, in a surpris-

\footnotetext{
${ }^{12}$ Agreement on the implementation mechanism for the transition process in Yemen in accordance with GCC, 2012.Para 20.
} 
ing move, the Houthi movement took unilateral action to enter the capital Sana'a without fighting except in places belonging to the Yemeni army, and declared the house arrest of the elected president and government members. The Special Envoy of the Secretary-General Jamal Ben Omar explained in his briefing: "[i]n a surprising move, Ansarullah (the Houthi movement) took unilateral action. They organised a gathering of their supporters at the Republican Palace, and announced a so-called "constitutional declaration." This declaration pronounced that parliament is dissolved, that a five-member presidential council would be formed and that a Supreme Revolutionary Committee would run the country temporarily" (Security Council, 2015).

\subsubsection{The Arab Coalition}

After the ousted president escaped to the port city of Aden, the Houthi movement sent troops to arrest him, but he eventually fled to Saudi Arabia and stayed there until today. On March 24, 2015, the ousted president requested assistance from Arab GCC, which responded by forming the Arab coalition led by Saudi Arabia. The coalition launched military intervention to restore the elected president and expel Houthi troops from the capital city and other major cities (Saudi Arabia's Embassy, 2015). Saudi Arabia, along with nine other states, launched a military operation (Decisive Storm) against the Houthi movement forces and supporters of the former Yemeni president, according to Saudi Arabia's media. Participating states pledged to participate in various military units including air, land and naval forces (e.g. Saudi Arabia had pledged to use 100 warplanes and contribute 150,000 soldiers) (Al Arabiya News, 2015), within the first hour of the operation. The coalition declared Yemeni airspace a restricted area, and Saudi Arabia started airstrikes that hit all places belonging to the Yemeni government, such as the Ministry of Defence, aircraft on the ground, air defences, military communications systems, facilities and bridges that link provinces. The Saudi spokesman for the coalition announced on April 21, 2015 that the coalition led by Saudi Arabia had ended its bombing campaign against rebels in Yemen. The Saudi Defence Ministry reported that " $t]$ he air campaign removed threats to the security of the Kingdom of Saudi Arabia and the security of neighbouring countries, through the destruction of heavy weapons and ballistic missiles captured by the Houthi militia" (Jeremy Bowen Report, 2015). A new operation called "Restoring Hope" concentrated on a political settlement and the war against terrorism in Yemen. See Figure 1.

\subsection{Motives for Military Intervention}

Any decision taken by a state to intervene directly and use military force in the internal affairs of another state includes declared motives, such as those announced by the Arab coalition led by Saudi Arabia, and ulterior motives.

\subsubsection{Legal Motives}

During the Cold War, another form of justification for military interference 


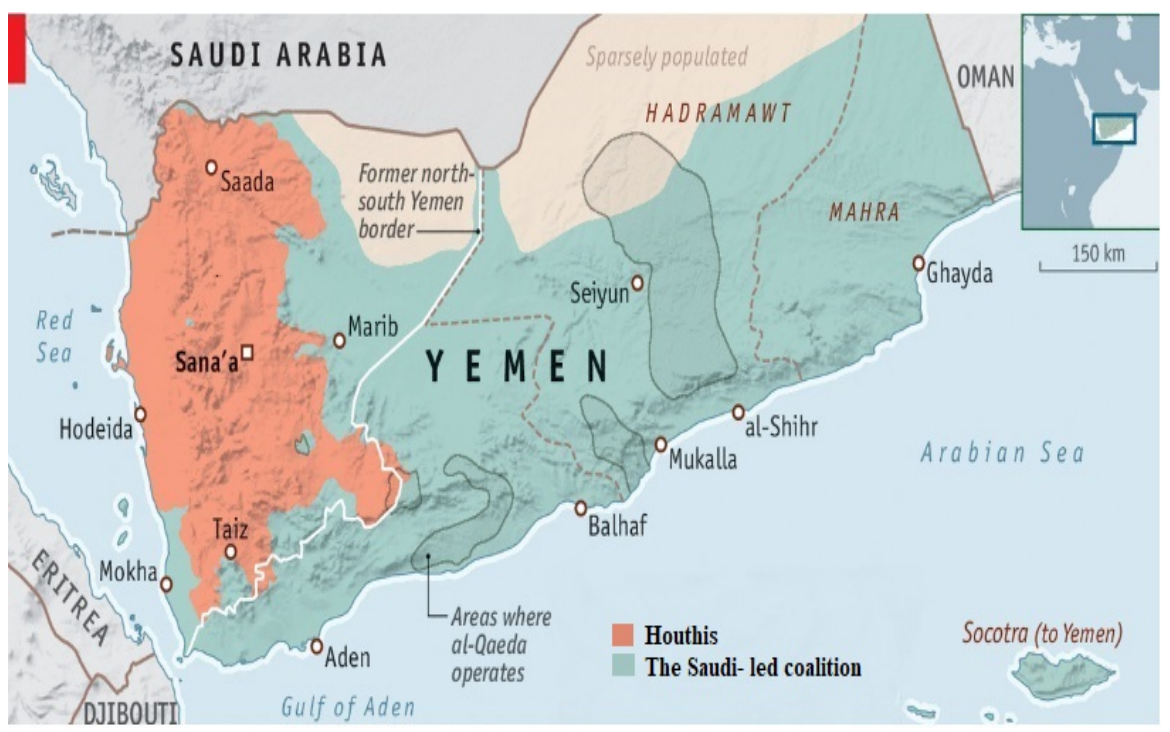

Source: Risk Intelligence.

Figure 1. Areas of control in Yemen, 2015-2018.

emerged between states. Interventions by invitation, or "consensual interventions", is defined by the International Law Institute as "[d]irect military assistance by the sending of armed forces by one State to another State upon the latter's request" (Hafner, 2011). Scholars agree that consensual interventions do not fall under the exceptions of Article 2 (4), nor do international treaties and conventions make reference to it. The legal relationship between the consent and intervention of states can therefore be interpreted as a bilateral agreement. The International Law Commission concluded that consent to interference functions as a form of a bilateral agreement between consenting and intervening states, in which states parties can agree to terminate or suspend the treaty at any time ${ }^{13}$. In all circumstances, the legitimacy of such action depends on the positions of states to accept or reject. Some states relied on consent to justify their interventions in certain developing countries to support friendly governments against rebels, which were accepted by most states. For instance, in 1964, several states accepted that the UK intervened in Tanganyika, Uganda and Kenya to support existing regimes in armed force mutinies (International Law Commission, 2001). In 1982, some states objected the deployment of the Reagan Administration of the United States, French, Italian and British forces to help restore stability to the Lebanese government (Office of the Historian). However, some of the measures based on consent proved unpersuasive and faced intense international criticism. For instance, when the Soviet Union relied on the principle of state consent to justify its interventions on Hungary ${ }^{14}$, Czechoslovakia ${ }^{15}$ and Afghani$\operatorname{stan}^{16}$, it faced widespread international criticism.

${ }^{13}$ International Law Commission, Draft articles on responsibility of states for internationally wrongful acts, 2 Yearbooks of the International Law Commission. (2001), at article 20 paragraph 2.

${ }^{14}$ U.N Doc. S/PV.746 (1956) (situation on Hung).

${ }^{15}$ U.N Doc. S/PV.1441 (1968) (situation on Czech).

${ }^{16}$ U.N Doc. S/PV.2185 (1980) (situation on Afg). 
The Arab coalition relied on the ousted president's call for direct involvement and the use of military force to support the government's legitimacy in Yemen and to eliminate threats to the security of Saudi Arabia and neighbouring countries as a legal reason for such action. The coalition claimed that such interference is in compliance with Article 2 (4) of the UN Charter. Hence, the president's authority to invite the Arab coalition to interfere and use military force is doubtful for several reasons. First, according to the initiative of the GCC, all political parties have agreed to grant the president a two-year duration to handle the transitional process, which ensures that the president has no authority to exercise presidential power by the end of this time. Part II paragraph 7(b) underlined that " $[t]$ he second phase, which shall last for two years, shall begin with the inauguration of the President following the early presidential elections". During the two years of the presidency, the stipulations in this agreement were not achieved, nor has the new national constitutional law been adopted. In fact, some political parties, including the president himself, have tried to extend the National Dialog Conference and the transition phase for personal purposes, which led to complaints from other political parties. Second, in democratic systems (a legislative system), a president's authorities are limited by the approval of the parliament who is elected by the people in the state. Many national constitutional laws of democratic countries restrict the powers of the president's duties, particularly in matters that raise the burden of the state and declare war or deploy military forces outside the borders of the state ${ }^{17}$. Consequently, any decision taken by the president including such responsibilities will not be effective before obtaining approval of the parliament. The Yemeni National Constitution stipulates that any agreements or treaties relating to issues of security, alliance, conciliation, peace or border matters shall not be binding until accepted by the Parliament, and the Parliament shall ratify all international agreements and treaties involving financial obligations on the part of the state or requiring a law for enactment (The Constitutional Law of the Republic of Yemen, 1991). In the case of declarations of a state of emergency, the constitutional law requires the president to send his decision to the parliament for approval within one week of the announcement ${ }^{18}$. Similarly, some national constitutional laws regulate states' external actions by restricting the lawful use of military force and providing the procedural basis for adoption. Ku and Jacobson (2003: p. 39) argued that "[a]long with the establishment of constitutional structures for regulating national military power, national constitutions have contributed to the evolution of contemporary international law prohibiting the use or threat of force in international relations". As the ousted president did not follow the procedures stipulated in national constitutional law, his call to the coalition is unconstitutional because two-thirds of the parliament was against such a request and the use of military force. Third, the invitation of the ousted president to the Arab coalition was

\footnotetext{
${ }^{17}$ For example; Article I, Section 8, Clause 11 of the U.S. Constitution grants Congress the power to declare war.

${ }^{18}$ Article 121.Ibid.
} 
based on three legal principles: the principle of self-defence in Article 51 of the UN Charter, the Arab League Charter and the Joint Arab Defence Treaty. All of these legal texts require an armed attack against a member state for exercising the right to self-defence where armed attack by a state with a regular army is presumed to occur. Therefore, states are not entitled to invoke the right to selfdefence unless a foreign state attacks. For instance, the Arab League Charter presumes that aggression or the threat of aggression occurs by "one state against a member-state, the state which has been attacked or threatened with aggression may demand the immediate convocation of the Council" (The Arab League Charter, 1945). Moreover, the problem arises when the government's consent to intervention is subject to challenge, either because the government has lost control over most of the state's regions or because the international legitimacy of the government is in doubt (Wippman, 1996b).

Prior to the invitation to the Arab coalition, many spectra of the Yemeni people supported the Houthi movement. At the beginning of 2015, the Houthi gradually took over all northern regions, including the capital Sana'a. Eventually, they tried to take control of the whole country by controlling the southern regions, including the city of Aden, and forced the ousted president to flee abroad in March 2015. The Arab coalition was called when the Houthi movement controlled most of the Yemeni regions. The coalition ground troops landed in Aden's southern port city in August 2015, helping the government drive the Houthi and their allies out of much of the southern regions after several months of military operations (BBC News Report, 2020c). This series of events leads to doubts about the president's legitimacy in practice, owing to the loss of control over most regions in Yemen. Scholars argue that interventions by invitation may gain legitimacy on condition that it is issued by a government that exercises effective control over its territory and its citizens. Besides, international law presupposes that when the government exercises effective control over its territory and its citizens, the government has the right to express the will of the state in its international affairs.

\subsubsection{Ideological Motives}

States usually support popular movements in other countries that have common interests or loyalties (revolutionaries or protesters). By contrast, states fight and oppose movements that they do not share common interests or loyalties with. One of the reasons for intervention and the use of military force in Yemen is the difference in doctrines and loyalties. In fact, the Houthi movement was in control of most of the Yemeni regions before the intervention began. It faced opposition from most neighbouring states, especially Saudi Arabia because of their different doctrines and loyalties. Saudi Arabia's rulers are accustomed to supporting Yemen's governments and tribal rulers who have been loyal to them over the past decades. Saudi Arabia supported the monarchists belonging to the Zaidi imamate, who governed the northern regions of Yemen for nearly a thousand years before it was overthrown in the Republican Revolution of 1962 (Hill 
\& Nonneman, 2011). After the 1962 revolution, Saudi Arabia supported the founding and financing of Salafi extremism teaching at the Zaidi Centre, which led to the emergence of the Houthi movement. The Houthi movement belongs to the Zaidi imamate. The group is considered a religious-political-armed movement against the ideas and teaching of Salafism, whose loyalty lies in Iran. The doctrine of the Houthi movement differs from the Twelver Shiism practiced in Iraq and Iran (Roland Popp $)^{19}$. The Yemeni government, backed by Saudi Arabia and the Muslim Brotherhood, fought the Houthi movement during six consecutive wars. The wars were originally meant to protest the dilution of Zaidi's identity and influence (Christopher Boucek, 2010). However, the Houthi movement claimed that they were the only representative of the Yemeni citizens after the president's overthrow in what they called a popular revolution. This revolution was considered an integral part of the country's uprising in 2011 after the Houthi leader called on his followers to begin demonstrations in Sana'a and other major cities to re-occupy Change Square (the protest centres) (Peter Salisbury Report, 2014). The control of the Houthi movement in Yemen over the reins of government led the Arab states to object and not to recognise their revolution. Therefore, the Arab states including Saudi Arabia committed to the legitimacy of the ousted president and have directly interfered with the use of military force to end this movement. The Arab states supported coups, armed movements and military interventions against states that contradict their foreign policy or have no loyalties. For instance, 1) In 2003, Iraq's neighbours in the Persian Gulf supported the US invasion of Iraq to overthrow the Iraqi government and maintain the status quo of a weak Iraq, rather than imposing a new Iraq, while retaining stability and security in the Gulf states (Alterman, 2007). 2) In 2012, GCC states recognised the Syrian Armed Opposition Coalition as a legal representative instead of the elected government. The League of Arab States Ministerial Council also urged regional and international organisations to recognise this alliance as a legitimate representative and a principal negotiator with the Arab League (Talmon, 2013). 3) The rise of the Muslim Brotherhood in Egypt led to opposition from most of the Arab Gulf states, including Saudi Arabia and UAE, who feared that Islamists would be emboldened against their policies. Thus, in 2013 the Egyptian army overthrew the democratically elected president with the economic and political support of these states (Patrick Werr Report, 2013).

\subsubsection{Geographical Motives}

Most Arab coalition states, predominantly Saudi Arabia and the UAE, are driven by commercial potential, regional security interests and a desire to shape the region's future of land or marine commerce. Recently, Saudi Arabia, the UAE, Qatar and Turkey are trying to extend their spheres of power by controlling commercial ports and establishing military bases along the Red Sea coasts. In 2013, China announced on political, strategic and geographical terms the Marine Silk Road Initiative (MSRI) and the Silk Road Economic Belt (SREB) (Blanchard ${ }^{19}$ Roland Popp. Ibid, at 2. 
\& Flint, 2017). These initiatives highlighted the importance of port sites for Red Sea countries and forced some regional and international states to extend their spheres of influence in those commercial ports. The SREB covers more than 60 countries, including Middle Eastern countries. It will connect Asia with African countries as a means of strong regional cooperation between countries to achieve political connectivity and unimpeded road and trade linkages (Qian, 2016). Although European merchant ships travel through the Suez Canal and the Bab al-Mandab Strait via the Gulf of Aden, several countries in East Africa such as Madagascar, Tanzania, Kenya, Somalia, Djibouti and Eritrea are the main destination for MSRI (Nouwens, 2019). The Chinese initiative has intensified regional rivalry between states seeking to be a major transit point in the initiative by providing services for ships passing between the East and the West. The interest of states in the regions in the initiative is not only to obtain economic and commercial benefits, but also political and security stability that will drive other beneficiaries to ensure the security and stability of these countries. The UAE has worked to optimise the role of the maritime and air transport sectors in the Chinese initiative. It has also underscored its ambition to be a leading player on the new silk road, after Gwadar Port has been officially leased to China for 43 years as one of the most significant ports for the implementation of the MSRI. Gwadar Port can compete with UAE ports by improving existing links to the Caspian region and conflicts of interest between them (Al-Rawashdeh \& Al Katatsheh, 2017). Therefore, the UAE, backed by Saudi Arabia, began expanding its spheres of influence through controlling commercial ports and establishing military bases in some African countries and Yemen, which is located on the MSR. Yemen is located on the banks of the Arabian Sea and the Red Sea. Its coastline extends for approximately 1200 miles and includes more than 200 islands, including the island of Socotra. Owing to its location near the Horn of Africa across the Bab al-Mandab Strait and the Gulf of Aden that may link Asian countries with African countries, some countries have attempted to control these ports. For example, Ottomans captured Aden City in August 1538 with their intention to use it as a base of operations against the Portuguese settlement on India's west coast (Kour, 2005). As one of the busiest ports in the world, Aden was the British Crown Colony in 1937-1967, attracting significant investments such as oil refineries and electricity, water and telephone investment (Holt, 2004). However, in 2008, through a corrupt deal between Dubai International Ports (DP World) and the former Yemeni government, the UAE tried to expand its influence over the port of Aden. Under this deal, DP World secured a long-term concession for the construction and operation of the Port of Aden, where DP World worked to disable this port during the four years of the concession. Disagreements over contracts with the new Yemeni government led to the termination of this agreement in 2012 (Market News Report, 2012). The Houthi movement's takeover of control of the southern regions, especially the coastal city of Aden, led to fears from neighbouring states (Saudi Arabia and the UAE) that the con- 
trol of these regions would lead to the operation and development of the ports or to the establishment of trade relations with Iran. As a result, exports and imports of their domestic and overseas ports would be adversely affected. The entry of Saudi Arabia and the UAE forces into a war against the Houthi movement under the justification of support for the so-called legitimacy of the Yemeni government has led to the strengthening of their armed forces in several strategic countries along the Red Sea and Gulf of Aden coasts. For instance, several military bases were established. In addition, the Eritrean government allowed the forces of Saudi Arabia and the UAE to use the old port of Assab as a starting point for their military forces against the Houthi movement. Many official sources have reported that Eritrea and the UAE have signed a 30-year lease agreement in $\mathrm{Assab}^{20}$. The UAE forces have also received a concession from the UAE's DP World in the Somali port of Berberaand (Horton, 2019). In the Port Bosasso in Puntland City by UAE's P\&O Ports, another 30-year concession for the control and establishment of military bases belongs to the UAE forces. See Figure 2 .

Figure 2 illustrates military bases and ports controlled by the UAE forces in Eritrea, Somalia and Yemen. The UAE army focused on controlling all of

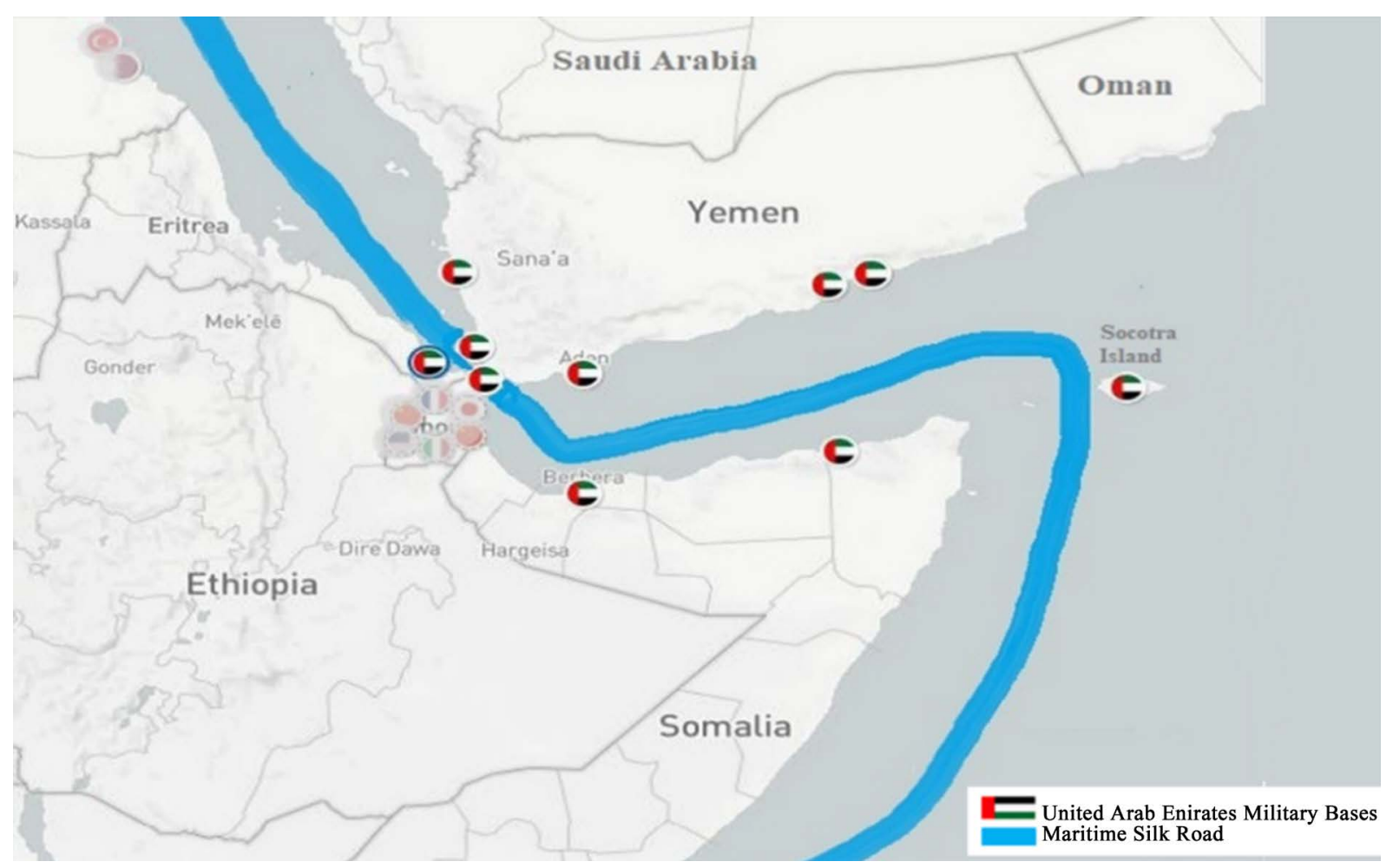
Source: Brookings Doha Center

Figure 2. United Arab emirates military bases.

${ }^{20} \mathrm{SC} / 2017 / 925$, Letter dated 2 November 2017 from the Chair of the Security Council Committee pursuant to resolutions 751 (1992) and 1907 (2009) concerning Somalia and Eritrea addressed to the President of the Security Council, at 15), available at: https://www.un.org/ga/search/view_doc.asp?symbol=S/2017/925. 
Yemen's southern coasts. These areas include a number of port cities and islands, such as port of Aden, Balhaf, Mukalla and Socotra Island in 2018 (these ports are under Yemeni government control and far from the Houthi movement) (Vertin, 2019), until the Hodeidah port, which remains under the control of the Houthi movement, according to the ceasefire agreement in 2018 (CNN News, 2018).

\section{Evaluation of Military Intervention in Yemen}

According to Article 2 (4) of the UN Charter and its exceptions, along with the motives for the military interventions in Yemen, the last question is whether the UN Charter is capable of continuing to urge states not to use military force in international relations with the rise of civil wars involving foreign states. The question arises especially because the provisions and articles of the Charter are flexible and face new challenges. This chapter attempts to evaluate the position of the international community, represented by the UNSC, on military intervention in Yemen and its impact.

\subsection{The Role of the International Community}

An evaluation of the international community's position first needs to evaluate the legal rules on which states rely in their conduct and transactions (the UN Charter) and evaluate the UNSC which has the authority to take action to preserve international peace and security.

\subsubsection{The UN Charter}

The Charter was officially adopted as a special international treaty establishing the UN with its unique international character and as a cornerstone of modern international law. The UN is meant to regulate international relations between states and to settle disputes between states after the aftermath of the two World Wars. Although this Charter is seen as an international constitution with a full structure and precedence over other international treaties because it was ratified by most states from 51 to $193^{21}$, it is distinguished by double constitutionality (Bardo Fassbender, 2009). It is recognised as a constitution of the international organisation and as a constitution of the international community. Some scholars emphasise that the Charter is a constitutional act of the Member States of the UN. Kelsen (2000: p. 3) affirmed that "[t]he Charter is certainly a more adequate designation of the constitution of an international community than the covenant". Yet as a reaction to two world wars, this Charter was drafted to avoid any conventional wars between states in the future. International events at the time of the adoption of the UN Charter were vastly different from current events today, such as international terrorist organisations, weapon of mass destruction and increased military interventions resulting in civil wars in most regions of the world (Yoo, 2004). Article 51 of the Charter used the term "armed attack" to de${ }^{21}$ GA Res.65/308. On 14 July 2011, the Republic of South Sudan was admitted as 193ed Member of the UN. (2011) 
scribe a condition for the exercise of the right to self-defence. However, the drafters did not provide a definition of this term, which led to all states having their own interpretation of the principle of self-defence in a manner consistent with their interests and national security to portray their own conduct as legitimate. Nor did the definition provide for UN interventions in cases of gross violations of human rights, destruction of democracy, the disintegration of effective governance, mass starvation and environmental degradation (Franck, 2002). Wheeler explained that " $[b]$ reaches of the prohibition were inevitably justified by the relevant states in terms of an exception to the rule (self-defence), rather than through denial of its binding force. While keen to portray their own conduct as lawful (Weller, 2010). Therefore, the Charter needs to be amended particularly the articles about the latest developments on international affairs and to prevent any foreign interventions that exist under a variety of justifications within the right to self-defence, such as anticipatory self-defence, preventive self-defence and consensual interventions ${ }^{22}$. This suggestion was confirmed at the closing session of the San Francisco Conference by US President Harry S. Truman (1945): "[t]his Charter, like our own Constitution, will be expanded and improved as time goes on. No one claims that it is now a final or a perfect instrument. It has not been poured into a fixed mold. Changing world conditions will require readjustments, but they will be the readjustments of peace and not of war". The continued application of Article 51 as it currently stands leads to continuing military interventions in the form of self-defence measures that are justified as matter of state interests and national security. Facts and figures indicate that some states refused to adhere to the principle of good faith in the treaty upheld by the Vienna Convention on the Law of the Treaties during military interventions under the justification of self-defence ${ }^{23}$. For instance, no agreement within the international community that the US approach to use force to fight terrorism under the justification for self-defence is acceptable, because the US has selected self-defence steps that are compatible with its interests and national security. Such approach is evident in the US military intervention in Iraq in 2003 (Anne Orford, 2004). The US decided for itself the best measures to take selfdefence without reference to the UN Charter requirements on the use of military force. Nevertheless, the US faced a great deal of opposition. The UN Secretary-General Kofi Annan declared that the military intervention in Iraq was illegal from the Charter point of view (BBC interview, 2004). However, this intervention was supported by some scholars who stated that American policymakers will not allow the provisions of the UN Charter to obstruct America's national interests and stability, which could contribute to its withdrawal from this organisation. Yoo and Trachman (2004: p. 379) emphasised: “[i]f American policymakers reach a consensus that important national security objectives are suf-

\footnotetext{
${ }^{22}$ Since its adoption in 1945 until today, the Charter has been modified only five times. See Charter of the United Nation, Introductory Note), available at:

https://www.un.org/en/sections/un-charter/introductory-note/index.html.

${ }^{23}$ Article 31, Vienna Convention on the law of treaties (23 May 1969).
} 
fering because of the United Nations, it will be difficult to justify adherence to the Charter rules on the use of force". Marie Slaughter also explained during the discussion on how best to disarm Iraq: "[m]ost international lawyers will probably reject this claim and find the use of force illegal under the terms of the Charter... The United Nations imposes constraints on both the global decision-making process and the outcomes of that process, constraints that all countries recognise to be in their long-term interest and the interest of the world. But it cannot be a straitjacket, preventing nations from defending themselves or pursuing what they perceive to be their vital national security interests" (Slaughter, 2003). After almost five years of military intervention, which resulted in numerous violations of international human rights and humanitarian law, the decision to intervene militarily in Iraq was declared a mistake. Hence, the US' interpretations of anticipatory self-defence and the views of the supporters were also mistaken. President George W. Bush announced that his presidency's biggest mistake was faulty evidence that Iraq had nuclear weapons (Reuters News, 2008). British Prime Minister Tony Blair also apologised and stated that Saddam had no immediate threat and that the evidence argument was not justified (BBC News, 2016). However, permitting consensual interventions based on self-defence leads to the emergence of further civil wars, as states may use the right to self-defence to counter antigovernment movements (e.g. revolutions, opposition political movements and selfdetermination) that often pursue democratic reforms or legislative changes and are protected by other internationals conventions such as the International Covenant on Civil and Political Rights in Articles 1, 19 and 21. It also leads to an increase in civil wars as each party of the government claims to represent the will of citizens. Problems become more complicated when the issue occurs in parliamentary structures consisting of two chambers. For instance, after the outbreak of civil wars in Libya with the support of international parties, Libya was governed by the National Accord Council. The council was the only legitimate executive authority, the parliament in which each party also claims to be the representative of the Libyan people. According to the agreements signed in several political, economic and security areas between Turkey and the National Accord Council, Turkey intervened directly and sent troops to support the UNbacked government against hostile forces under the justification of consensual intervention and safeguarding the common interests (BBC News, 2020a). Egypt, Libya's closest neighbour, felt the danger of this intervention, especially in the areas bordering the two countries, and declared that it would intervene militarily to defend its security and national interests under self-defence justification. Their stance was backed by the principle of consensual interference between the Egyptian government and the Libyan parliament (Reuters News, 2020).

\subsubsection{UN Security Council}

The response of the UNSC was positive about some past military interventions and violations of international law, such as the involvement of South Africa in Namibia in 1985, Iraq's invasion of Kuwait in 1990, Iraqi government attacks on 
Iraqi Kurds and Shiites in 1991, Somalia's widespread malnutrition in 1994 and ethnic violence that constituted genocide in Rwanda in 1994. Some scholars argue that the adoption of certain resolutions for military intervention or through material and logistical support is a war necessary and fair under legitimate justifications for the protection of international peace. However, recent events have shown that the UNSC's decisions are paralyzed and have a purely political dimension because of the states seeking to adopt a military intervention resolution with political and military objectives, which led to many civil wars (armed groups) and human rights violations. During the 2011 Arab Spring, France was one of the main promoters of the idea of military intervention in Libya to protect demonstrators and to overthrow the Gaddafi regime, whose policy was against the interests of France, particularly in the Horn of Africa. France persuaded the members of the UNSC to adopt two resolutions (1970 and 1973), which paved the way for military intervention. It was also the first country to take part in the military intervention against the President of Libya and the first foreign Head of State to recognise the Transitional National Council as Libya's legitimate governing authority. France was joined by the UAE and some Arab states, which resulted in the outbreak of civil wars and the emergence of many armed groups that have increased human rights violations to this day (Barah Mikail, 2011). The events in Yemen have proven that the UNSC's authority to determine acts of aggression and human rights abuses is affected by its member states' interests and policies. Ayoob (2002: p. 6) explained that "[t]he national interest of majority powers determines the decision regarding humanitarian intervention is strengthened by the fact, Military operation under Chapter VII (undertaken for humanitarian purpose) are agreed largely on the basis of calculus od shared interest or of trade-offs among the five permanent members of the Security Council". Within one of its resolutions, a month before the start of the military intervention in Yemen, the UNSC requested that the Houthi movement participate in good faith in the UN-brokered talks and withdraw its forces from the government institutions. In addition, the UNSC called on all Member States to refrain from external interference leading to conflict and instability ${ }^{24}$. After a month of military intervention, the UNSC reiterated its support for the actions of the GCC in facilitating the political process, rather than criticising this interference for breaching the UN Charter and its call in the last resolution. The UNSC provided political and legal cover in the form of a strongly worded resolution in line with the initiative of Saudi Arabia and the UAE calling on the Houthi movement to comply with the GCC Initiative and its implementation mechanism and other agreements. Additionally, weapon embargoes and freezing of funds for some leaders of the Houthi movement and the former president and some of his relative were implemented ${ }^{25}$. Contrary to the resolutions related to Libya, in one of its resolutions, the UNSC decided to refer the situation in Libya to the ICC prosecutor and adopted an arms embargo, a travel ban for certain members of ${ }^{24}$ SC Res.2201 (2015).

${ }^{25}$ SC Res.2216 (2015). 
the Gaddafi government and a freeze on their funds ${ }^{26}$. In its second resolution, it explicitly authorised Member States to take all necessary measures to protect civilians under threat of attack in Libya and to take all necessary measures to enforce compliance with the flight ban. This resolution prompted certain states to intervene militarily in the implementation ${ }^{27}$. The UNSC failed to adopt a resolution preventing the Arab coalition led by Saudi Arabia from military intervention in Yemen pursuant to Article 2 of the UN Charter. The failure led to more conflicts and instability rather than a peaceful political transition due to the support of most member states. Westra (2007: p. 1) affirmed that "[s]ince the Charter came into effect on 24 October 1945, there have been numerous incidents in which the major powers (at least arguably) violated this prohibition, although they offered arguments to the contrary and the Security Council either failed to approve a resolution addressing the legality of the actions taken or was prevented from doing so because of the veto that the major powers wield in their capacity as the five permanent members of the Security Council". In the last five years, the Arab coalition led by Saudi Arabia has gained political support from UNSC permanent members for their regional affairs through billions of US dollars in arms purchases, oil deals and investment. See Figure 3.

Figure 3 shows the measure of major conventional weapon supplies from some member states of the UNSC. The US, UK and France are the first largest suppliers of Arab states in the coalition. The US also provided logistical and

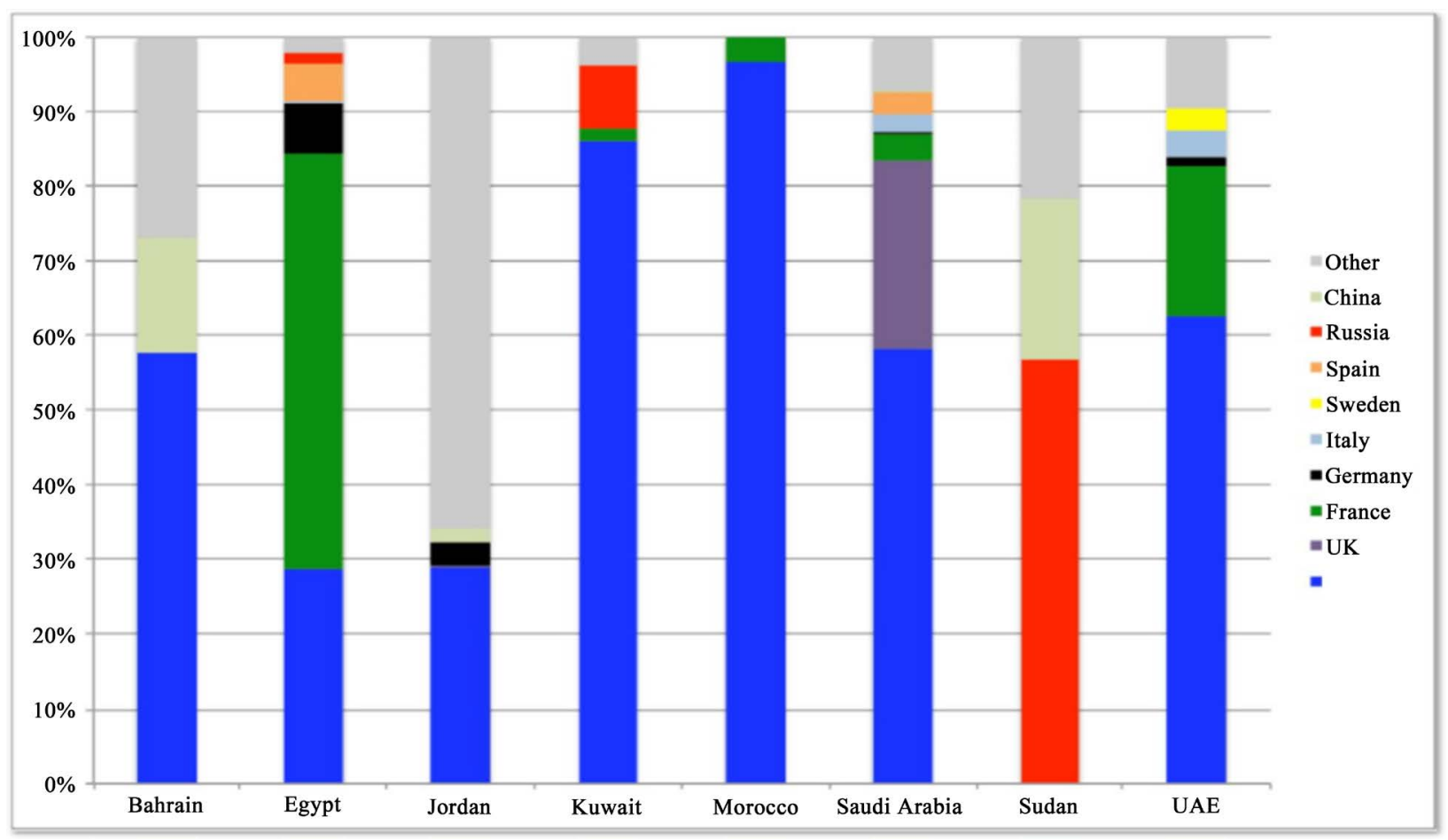

Source: World Peace Foundation based on the SIPRI TIV.

Figure 3. Share of major arms deliveries 2015-2016 to each recipient by the supplier.

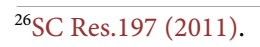

${ }^{27}$ SC Res.1973 (2011). 
intelligence support for military operations, where the US Central Command were deployed to provide related support and mid-air refuelling of coalition aircraft (Sharp, 2018). Besides, the Saudi Arabia has invested billions of dollars in technological enterprises, steel industry, hotels, real estate and media institutions in those countries ${ }^{28}$. Therefore, the influence of Saudi Arabia and the UAE in the UNSC was strengthened during the war by the three permanent members of the Council (US, UK and France), including Russia and China. These two countries usually act to use their veto against US dominance on the Council, but due to the intention of enhancing their economic relations with Saudi Arabia and the UAE, they abstain from vote (Xu \& Chen, 2020).

Non-permanent member states aligned with Saudi Arabia and the UAE also affected the positions of the Council, such as Jordan (2014-2015), Egypt (20162017) and Kuwait (2018-2019) (UNSC News, 2013, 2015). All members of the Arab military coalition led by Saudi served as proxies for Saudi Arabia to justify its military intervention and to draft all resolutions issued pursuant to its plans during their rotations in the Council. Over the last five years, all the resolutions concerning Yemen have been considered by a council overwhelmed by the influence of Saudi Arabia and the UAE with their ability to spend money strategically. These investments aim to enforce their conditions in compliance with Resolution 2216, which calls on the Houthi movement to withdraw its forces from all the regions they seized and to abandon all additional weapons that have been seized from the military and security institutions, including missile systems. The influence of Saudi Arabia has also prevented the international community, represented by the UN General Assembly and UNSC, from attempting to find another peaceful means to stop the war. In general, Saudi Arabia and the UAE's insistence on surrendering the Houthi movement and making this war as a battle between the Yemeni parties has contributed to prolonging the war for more than five years and the growing violations of human rights, as well as the suffering of the Yemeni citizens. As a result, the re-establishment of democratic governments would lead states who support some governments' policy to adopt customary rules and allowing military intervention under a justification of support for democracy without the authority of the UNSC, which is contrary to the provisions and principles of Article 2 of the UN Charter.

\subsection{Conflicting Parties and Human Rights Violations in Yemen}

After more than five years, the actions and roles of conflicting parties in Yemen have definitely changed, resulting in more human rights violations. This part will evaluate the roles of the conflicting parties as well as the effects of military

\footnotetext{
${ }^{28}$ For example; Scott Lanman, Saudi Arabia Held \$52.4 Billion of U.S. Stocks as of June 2015, Bloomberg Business, (May 31, 2016), available at:

https://www.bloomberg.com/news/articles/2016-05-31/saudi-arabia-held-52-4-billion-of-u-s-stocksas-of-june-2015. Also See, Sam Bridge, Middle East Investors Target $\$ 5.3$ bn London Commercial Property Spend in 2020, Arabian Business, (February 5, 2020), available at:

https://www.arabianbusiness.com/banking-finance/439383-middle-east-investors-target-53bn-londo n-commercial-property-spend-in-2020.
} 
intervention in Yemen.

\subsubsection{Parties Involved in the Conflict in Yemen}

By the end of the fifth year of the war, no initiatives have been made to resolve the dispute between the parties involved in the war in Yemen, because Yemen is considered less strategic important for the interests of the permanent members than Saudi Arabia. As with other problems and humanitarian crises (Syria and Libya), the UNSC member states tends to leave diplomatic initiatives for Yemen to the Special Envoy of the Secretary-General, Martin Griffiths, a former British diplomat. The reason for establishing the UN envoy's mission in 2012 prior to the military intervention was to represent the international position in support of facilitating Yemen's transition and the implementation of the agreements and supporting other transitional steps, including constitutional review, and new general elections (The OSESGY website). However, following the military intervention, this mission was supposed to change and work to stop this interference and continue to engage the Yemeni parties, including Saudi Arabia, in dialogue. Saudi Arabia also affected this mission by making it proceed with its preceding objectives. For example, since his appointment on February 16, 2018 and at every briefing session of the Council (21 of 33 sessions), the UN envoy has been working to prove that the parties in the Yemeni conflict are only Yemeni, and that the Arab coalition led by Saudi Arabia is supporting political talks between the Yemeni parties. The UN envoy has focused on calling all the Yemeni parties into the political dialogue table. Instead of seeking to prevent continued military interference and human rights abuses in Yemen, the UN envoy focused on preventing fighting between the Yemeni parties in some regions, such as fighting in some southern and northern regions, and the port of Hodeida (11 of 21 briefing sessions), which resulted in a continuing period of conflict ${ }^{29}$. However, the roles of the parties to the conflict in Yemen have changed. After Saudi Arabia, the UAE and Bahrain broke relations with Qatar in 2017, Qatar split from the Arab coalition (BBC News, 2017). The UAE has also strengthened its control over the southern regions by directly supporting the Southern forces and carrying out an air strike against the forces of the ousted president resulting in the Jeddah Agreement in 2019 (Routers News, 2019). The UAE also indirectly helped the Southern forces to occupy the Socotra Island, which was accused by the government of the ousted president of the coup in 2020 (BBC News Report, 2020b). The Houthi movement tightened its power over the regions it controlled and simultaneously obtained certain regions that were under the control of the forces of the ousted president and recognised as a de facto government. The Houthi movement also had indirect talks with Saudi Arabia (Aljazeera News, 2019). Therefore, what caused the Houthi movement to stand up during this time? One of the most important reasons that made the Houthi movement stand up during

\footnotetext{
${ }^{29}$ The budget of the office of the special envoy of the UN Secretary-General for Yemen in the poorest country whose civilians need for little aids exceeds the mission's outputs. For instance: In 2020 a budget of about $\$ 18.4$ million was announced, available at: https://osesgy.unmissions.org/budget.
} 
that period was the inability of the internationally recognised government to exercise its work in the regions under its control, and because of the financial and administrative corruption that characterised most members of the legitimate government. These failures made Yemeni civilians bow to the de facto government. Military intervention by Saudi Arabia without a UNSC authority also resulted in the majority of Yemeni citizens opposing this interference, particularly in regions controlled by the Houthi movement. Hence, the Houthi movement was strengthened as a de facto government. The Arab coalition led by Saudi Arabia has failed in the pro-democratic justifications, as most pro-democracy actions have also failed to find consensus on their justifications for interference, because most states did not accept it as a legal doctrine. Gray (2018: p. 56) explained that "[s]tates may use force in 'pro-democratic' invasions to ensure democratic government in a foreign state has not proved attractive to states. The political goals underlying the use of force may include the re-establishment of 'democratic' government, but this has not led states to espouse a legal doctrine of 'pro-democratic' invasion without UN authority".

\subsubsection{The Human Rights Situation in Yemen}

Regardless of how long the military intervention will continue in Yemen, it will certainly end with a peaceful and diplomatic settlement such as the US-Taliban peace agreement and other military interventions (Lindsay Maizland Report, 2020). Such resolution makes restoring the country back to its previous state before the intervention difficult, particularly after serious human rights abuses have occurred. After the start of the military intervention in Yemen, numerous abuses of human rights have occurred according to international humanitarian law and international human rights law. The war in Yemen has greatly deteriorated the humanitarian situation. According to the United Nations Office for the Coordination of Humanitarian Affairs in December 2019, Yemen was the worst humanitarian crisis in the world and the extent of humanitarian needs is overwhelming. Approximately $80 \%$ of the 25 million people require humanitarian assistance, and 230 of the 333 districts in Yemen (69\%) are at risk of starvation. More than 862,607 suspected cases of cholera have been confirmed by the end of December 2019, and more than 3.43 million people are internally displaced across the country. Approximately 1 million have returned to their homes that have been destroyed (The United Nations Office for the Coordination of $\mathrm{Hu}$ manitarian Affairs, 2019). The emergence of the new coronavirus has also contributed to a rise in the humanitarian crisis, according to the World Health Organisation in August 2020. A total of 1808 new cases of COVID-19 have been confirmed in Yemen with 516 related deaths, which is a rise from 973 cases recorded and 285 deaths in June (World Health Organisation, 2020). Moreover, all parties involved in the conflict in Yemen have committed grave violations of international humanitarian law and international human rights law, including the Houthi movement and its allies, the forces of the coalition states, the forces of the ousted president, some tribes, terrorist networks, Yemeni militias and mer- 
cenaries hired and brought to Yemen by the UAE. Approximately 450 Latin American troops are also Panamanian, Salvadoran and Chilean soldiers (Hager \& Mazzetti, 2015). According to the UN High Commissioner for Human Rights, 7292 civilians (including at least 1959 children and 880 women) and 11,630 civilians (including 2575 children and 1256 women) were killed in Yemen as a direct result of the armed conflict between March 2015 and June 2019, respectively, when the coalition led by Saudi Arabia and the UAE participated in the conflict $^{30}$. The coalition led by Saudi Arabia and the UAE with the ousted president continued to bomb civilian objects and carried out indiscriminate attacks that killed and wounded thousands of civilians. For instance, from the start of the military intervention until the end of May 2017, Yemen received nearly 90,000 air strikes from Coalition forces (an average of one air strike every 12 minutes) mainly targeted at regions under the control of the Houthi movement (Elayah, Schulpen, Abu-Osba, and Al-Zandani, 2017). They committed serious violations of international humanitarian law and international human rights law, and inaccurate munitions were used in certain attacks, including large and largescale bombs that caused deaths and damages outside the sites of direct strikes (World News, 2015). Some attacks were indiscriminate, disproportionate and directed against civilians and civilian objects, including residential areas and gatherings such as weddings and funerals. Although the Houthi forces dominate large parts of the country, they indiscriminately shelled residential communities in Yemen, crushed all protests against their authority and deprived civilians of their right to freedom of speech and the use of arbitrary detention, forced disappearance and torture under the justifications of fighting against the states of intervention and their supporters. The persistent use of air, sea and land blockade by the Coalition states aggravated the situation, in addition to the loss of all Yemen's resources between the parties to the conflict and the continued refusal to pay the salaries of all government employees ${ }^{31}$.

\section{Conclusion}

The UN Charter urged all Member States to refrain from the threat or use of force in their international relations and took steps to regulate the use of force by imposing restrictions on the exercise of the right of self-defence. Nevertheless, civil wars continued to increase in some countries, resulting from foreign interventions in domestic affairs directly by the use of force under justifications of consensual intervention to support pro-democratic parties, or indirectly through material and logistical support for the protection of people against states that oppose their policies. Hence, violations of human rights and the emergence of

${ }^{30} \mathrm{~A} / \mathrm{HRC} / 42 / 17$, Report of the Group of Eminent International and Regional Experts as submitted to the United Nations High Commissioner for Human Rights(9 August 2019).

${ }^{31}$ The Special Envoy of the Secretary-General Martin Griffiths made several proposals to open Sana'a airport and pay the salaries of all state employees, but he failed due to the rejection of all parties to these proposals, especially the Arab coalition led by Saudi Arabia, the last time was on April 16, 2020 at a briefing to the UNSC, available at:

https://osesgy.unmissions.org/sites/default/files/seco briefing 16 apr 2020 en 1.pdf. 
terrorist organisations increased. The issue of consensual interventions and the use of military force as a justification increase the complexity of solutions to most civil wars, especially when different bodies are representative of citizens. All parties to the conflict continues to adhere to their positions on the surrender of the other party, whether internal or external, and not making any concessions. This effort requires the international community to address the conflicting parties neutrally and urge them to stop the war and discuss at the negotiation table. Foreign states are also compelled to stop direct and indirect interventions.

\section{Conflicts of Interest}

The authors declare no conflicts of interest regarding the publication of this paper.

\section{References}

(2008). Tabassum Zakaria Report: Bush Calls Flawed Iraq Intelligence Biggest Regret, Reuters.

https://www.reuters.com/article/us-bush1/bush-calls-flawed-iraq-intelligence-biggest-r egret\%20idUSTRE4B071020081201

(2011). GA Res.65/308. On 14 July 2011, the Republic of South Sudan was admitted as 193ed Member of the UN.

(2015). Security Council Briefing on the Situation in Yemen, Special Adviser to the Secretary-General Jamal Benomar.

(2015). The Embassy of the Kingdom of Saudi Arabia, GCC Issues Statement on Yemen, Washington $D C$.

https://www.saudiembassy.net/statements/gcc-issues-statement-yemen

(2018). Hamdi Al Khshali Report, Yemen Ceasefire Goes into Effect in Strategic Port City of Hodeidah, CNN News.

https://www.cnn.com/2018/12/17/world/yemen-ceasefire-takes-effect-hodeidah/index. $\underline{\mathrm{html}}$

(2019). Mohammed Mukhashaf Report UAE Carries Out Air Strikes against Yemen Government Forces to Support Separatists, Routers.

https://www.reuters.com/article/us-yemen-security/uae-carries-out-air-strikes-againstyemen-government-forces-to-support-separatists-idUSKCN1VJ17F

A/HRC/42/17, Report of the Group of Eminent International and Regional Experts as submitted to the United Nations High Commissioner for Human Rights (9 August 2019).

Abi-Saab, G. (1987). General Course in Public International Law. Recueil Des Course DE L'ACADÉMIE DE Droit International De La Haye (RCADI), HAIA, 207.

Agreement on the Implementation Mechanism for the Transition Process in Yemen in Accordance with GCC, 2012. Para 20.

Aljazeera News Report (2019). Saudi, Yemen's Houthis Hold "Indirect Talks" in Oman to End War.

https://www.aljazeera.com/news/2019/11/saudi-yemen-houthis-hold-indirect-talks-om an-war-191113160747944.html

Al-Rawashdeh, M. S., \& Al Katatsheh, M. H. (2017). China's Strategy in the Middle East (The Silk Road Project). IOSR Journal of Humanities and Social Science, 22, 37-51. https://doi.org/10.9790/0837-2201043751 
Alterman, J. B. (2007). Iraq and the Gulf States: The Balance of Fear (p. 31). Washington DC: United States Institute of Peace.

Armed Activities in Congo (2005). https://www.icj-cij.org/en/case/116/judgments

Article (1) Constitution of the United Kingdom of Great Britain and Northern Ireland.

Article (3) France's Constitution of 1958.

Article 121. Ibid.

Article 31, Vienna Convention on the Law of Treaties (23 May 1969).

Article 6 of the Arab League Charter, 22 March 1945.

Article 92 of the Constitutional Law of the Republic of Yemen, 1991.

Ayoob, M. (2002). Humanitarian Intervention and State Sovereignty. The International Journal of Human Rights, 6, 81-102. https://doi.org/10.1080/714003751

BBC Interview (2004). Lessons of Iraq War Underscore Importance of UN CharterAnnan.

https://news.un.org/en/story/2004/09/115352-lessons-iraq-war-underscore-importance -un-charter-annan

BBC News (2016). Chilcot Report: Tony Blair's Iraq War Case Not Justified. https://www.bbc.com/news/uk-politics-36712735

BBC News Report (2017). Qatar Crisis: What You Need to Know. https://www.bbc.com/news/world-middle-east-40173757

BBC News Report (2020a). Libya Conflict: Turkey Sends Troops to Shore up UN-Backed Government. https://www.bbc.com/news/world-africa-51003034

BBC News Report (2020b). Yemen Crisis: Separatists Take over "Galapagos of Indian Ocean”. https://www.bbc.com/news/world-middle-east-53129564

BBC News Report (2020c). Yemen Crisis: Why Is There a War? https://www.bbc.com/news/world-middle-east-29319423

Blanchard, J.-M. F., \& Flint, C. (2017). The Geopolitics of China's Maritime Silk Road Initiative. Abingdon-on-Thames: Taylor \& Francis. https://doi.org/10.1080/14650045.2017.1291503

Bori Szabo, K. T. (2011). Anticipatory Action in Self-Defense: Essence and Limits under International Law. Berlin: Springer Science \& Business Media. https://doi.org/10.1007/978-90-6704-796-8

Boucek, C. (2010). War in Saada: From Local Insurrection to National Challenge. Washington DC: Carnegie Endowment for International Peace.

Bridge, S. (2020). Middle East Investors Target $\$ 5.3$ bn London Commercial Property Spend in 2020. Arabian Business, February 5, 2020.

https://www.arabianbusiness.com/banking-finance/439383-middle-east-investors-targe t-53bn-london-commercial-property-spend-in-2020

Brownlie, I. (1980). The Relations of Nationality in Public International Law. BRIT. YB INT'L L., 39, 257.

de Tangle, G. S. (2015). The Objective International Responsibility of States in the Inter-American Human Rights System. Mexican Law Review, 7, 115-133. https://doi.org/10.1016/S1870-0578(16)30005-1

Elayah, M. A. A., Schulpen, L. W. M., Abu-Osba, B., \& Al-Zandani, B. (2017). Yemen: A Forgotten War and an Unforgettable Country.

Fassbender, B. (2009). The United Nations Charter as the Constitution of the International Community, $\$ 51$ (Brill.). 
For Example; Article I, Section 8, Clause 11 of the U.S. Constitution Grants Congress the Power to Declare War.

Franck, T. M. (2002). Recourse to Force State Action against Threats and Armed Attacks (p. 15). Cambridge: Cambridge University Press. https://doi.org/10.1017/CBO9780511494369

GA CN.4/SR.1627.

GA Res. 42/22,42nd sess (1987).

GA Res.2131 (XX), 21 December 1965, par 1.

GA Res.2625 (XXV), 1970.

Gray, C. (2018). International Law and the Use of Force. Oxford: Oxford University Press. https://doi.org/10.1093/law/9780198808411.001.0001

Green, J. A. (2009). The International Court of Justice and Self-Defense in International Law. London: Bloomsbury Publishing.

Hafner, M. G. (2011). Present Problems of the Use of Force in International Law. SubGroup C-Military Assistance on Request, Institute of International Law, Session of Rhodes.

Hager, E. Y. B., \& Mazzetti, M. (2015). Emirates Secretly Sends Colombian Mercenaries to Yemen Fight. The New York Times, 25.

Hill, G., \& Nonneman, G. (2011). Yemen, Saudi Arabia and the Gulf States: Elite Politics, Street Protests and Regional Diplomacy. London: Chatham House.

Holt, M. (2004). Memories of Arabia and Empire: An Oral History of the British in Aden. Contemporary British History, 18, 93-112. https://doi.org/10.1080/13619460412331296928

Horton, M. (2019). The Race for Bases, Ports, and Resources in the Horn of Africa Heats Up. Washington DC: the Jamestown Foundation (Global Research \& Analysis), October 11 .

https://jamestown.org/program/hot-issue-the-race-for-bases-ports-and-resources-in-th e-horn-of-africa-heats-up

ICJ (1986). Case Concerning Military and Paramilitary Activities in and against Nicaragua. ICJ Report.

ICJ (2003). Case Concerning Oil Platforms, Iran v, 6 United States of America ICJ, Decision.

ICJ Report (2005). Case Concerning Armed Activities on the Territory of the Congo. Democratic Republic of the Congo v. Uganda.

International Law Commission (2001). Draft Articles on Responsibility of States for Internationally Wrongful Acts, 2 Yearbooks of the International Law Commission. At Article 20 Paragraph 2.

Jeremy Bowen Report (2015). Yemen Conflict: Saudi Arabia Ends Air Campaign. BBC News, 21 April 2015. https://www.bbc.com/news/world-middle-east-32402688

Keely, C. B. (1995). Humanitarian Intervention and Sovereignty: Mit Deutscher Zusammenfassung. Konrad-Adenauer-Stiftung, Bereich Forschung und Beratung, Internat. Politik.

Kelsen, H. (2000). The Law of the United Nations: A Critical Analysis of Its Fundamental Problems: With Supplement (p. 11). Clark, NJ: The Lawbook Exchange, Ltd.

Kour, Z. H. (2005). The History of Aden. London: Routledge.

Ku, C., \& Jacobson, H. K. (2003). Democratic Accountability and the Use of Force in In- 
ternational Law. Cambridge: Cambridge University Press.

Lanman, S. (2016). Saudi Arabia Held \$52.4 Billion of U.S. Stocks as of June 2015. Bloomberg Business, May 31, 2016.

https://www.bloomberg.com/news/articles/2016-05-31/saudi-arabia-held-52-4-billionof-u-s-stocks-as-of-june-2015

Lindsay Maizland Report (2020). U.S.-Taliban Peace Deal: What to Know, the Council on Foreign Relations.

https://www.cfr.org/backgrounder/us-taliban-peace-deal-agreement-afghanistan-war

Maftei, J. (2015). Sovereignty in International Law. Acta Universitatis Danubius. Juridica, 11, 54-65.

Mahmoud Mourad Report (2020). Egypt Has a Legitimate Right to Intervene in Libya, Sisi Says. Reuters News.

https://www.reuters.com/article/us-libya-security-egypt/egypt-has-a-legitimate-right-t o-intervene-in-libya-sisi-says-idUSKBN23R0W1

Malanczuk, P. (1987). Countermeasures and Self-Defense as Circumstances Precluding Wrongfulness in the International Law Commission's Draft Articles on State Responsibility.

Market News Report (2012). Yemen's Aden Port to Cancel DP World Deal-Official. Reuters.

https://www.reuters.com/article/yemen-port-dpworld/yemens-aden-port-to-cancel-dp -world-deal-official-idUSL5E8JQ2ZX20120826

Mcdougal, M. S., \& Feliciano, F. P. (1961). Law and Minimum World Public Order: The Legal Regulation of International Coercion. New Haven, CT: Yale University Press.

Mikail, B. (2011). France and the Arab Spring: An Opportunistic Quest for Influence. Fundación para las Relaciones Internacionales y el Diálogo Exterior.

Nicaragua v. United States (1986). https://www.icj-cij.org/en/case/70/judgments

Nouwens, V. (2019). China's 21st Century Maritime Silk Road. Implications for the UK. London: RUSI Occasional Paper.

Office of the Historian, Foreign Service Institute. The Reagan Administration and Lebanon, 1981-1984. United States Department of State. https://history.state.gov/milestones/1981-1988/lebanon

Oil Platforms Case (2003). https://en.wikipedia.org/wiki/Oil Platforms case

Orford, A. (2004). The Gift of Formalism Bruno Simma: The Charter of the United Nations: A Commentary. Oxford: Oxford University Press.

Pattison, J. (2010). Humanitarian Intervention and the Responsibility to Protect: Who Should Intervene? Oxford: Oxford University Press. https://doi.org/10.1093/acprof:oso/9780199561049.001.0001

Popp, R. (2015). War in Yemen: Revolution and Saudi Intervention. CSS Analyses in Security Policy, No. 175.

https://css.ethz.ch/content/dam/ethz/special-interest/gess/cis/center-for-securities-stud ies/pdfs/CSSAnalyse175-EN.pdf

Qian, X. W. (2016). The New Silk Road in West Asia under “the Belt and Road” Initiative. Journal of Middle Eastern \& Islamic Studies, 10, 26-55. https://doi.org/10.1080/19370679.2016.12023277

Reisman, W. M. (1990). Sovereignty and Human Rights in Contemporary International Law. American Journal of International Law, 84, 866-876.

https://doi.org/10.2307/2202838

Roland Popp, Ibid, at 2. 
Ruys, T. (2010). "Armed Attack" and Article 51 of the UN Charter: Evolutions in Customary Law and Practice (p. 74). Cambridge: Cambridge University Press. https://doi.org/10.1017/CBO9780511779527

Salisbury, P. (2014). Yemen Capital Hit by Anti-Government Rallies. Aljazeera News, 20 Aug. https://www.aljazeera.com/news/middleeast/2014/08/yemen-houthis-rally-oust-govern ment-201481812414798870.html

SC Res.1264 (1999).

SC Res.197 (2011).

SC Res.1973 (2011).

SC Res.2201 (2015).

SC Res.2216 (2015).

SC Res.678 (1990).

SC Res.794 (1992).

SC Res.85 (1950).

SC/2017/925, Letter Dated 2 November 2017 from the Chair of the Security Council Committee Pursuant to Resolutions 751 (1992) and 1907 (2009) Concerning Somalia and Eritrea Addressed to the President of the Security Council, at 15). https://www.un.org/ga/search/view doc.asp?symbol=S/2017/925

Sharp, J. M. (2018). Yemen: Civil War and Regional Intervention. Washington DC: Congressional Research Service.

Since Its Adoption in 1945 until Today, the Charter Has Been Modified Only Five Times. See Charter of the United Nation, Introductory Note. https://www.un.org/en/sections/un-charter/introductory-note/index.html

Slaughter, A.-M. (2003). Good Reasons for Going around the U.N. The New York Times, March 18.

https://www.nytimes.com/2003/03/18/opinion/good-reasons-for-going-around-the-un. $\underline{\mathrm{html}}$

Staff Writer (2015). Saudi "Decisive Storm” Waged to Save Yemen. Al Arabiya News, 25 March 2015.

https://english.alarabiya.net/en/News/middle-east/2015/03/26/GCC-states-to-repel-Ho uthi-aggression-in-Yemen-statement-.html

Stephen, K. (1999). Sovereignty: Organized Hypocrisy. Princeton, NJ: Princeton UP. https://doi.org/10.1515/9781400823260

Symes, G. A. (1997). Force without Law: Seeking a Legal Justification for the September 1996 US Military Intervention in Iraq. The Michigan Journal of International Law, 19, 581-601.

Talmon, S. (2013). Recognition of Opposition Groups as the Legitimate Representative of a People. Chinese Journal of International Law, 12, 219-253.

https://doi.org/10.2139/ssrn.2227615

The Budget of the Office of the Special Envoy of the UN Secretary-General for Yemen in the Poorest Country Whose Civilians Need for Little Aids Exceeds the Mission's Outputs. For Instance: In 2020 a Budget of about \$ 18.4 Million Was Announced. https://osesgy.unmissions.org/budget

The OSESGY. https://osesgy.unmissions.org/background

The Special Envoy of the Secretary-General Martin Griffiths Made Several Proposals to Open Sana'a Airport and Pay the Salaries of All State Employees, But He Failed Due to 
the Rejection of All Parties to These Proposals, Especially the Arab Coalition Led by Saudi Arabia, the Last Time Was on April 16, 2020 at a Briefing to the UNSC.

https://osesgy.unmissions.org/sites/default/files/seco briefing 16 apr 2020 en 1.pdf

The United Nations Office for the Coordination of Humanitarian Affairs (2019). Yemen Humanitarian Dashboard.

Thomas, R. G. (2003). Yugoslavia Unraveled: Sovereignty, Self-Determination, Intervention. Lexington Books.

https://www.amazon.com/Yugoslavia-Unraveled-Sovereignty-Self-Determination-Inte rvention/dp/0739107577

Truman, H. S. (1945). Address in San Francisco at the Closing Session of the United Nations Conference.

U. N. Charter art.1, par.2.

U. N. Charter art.2, par.7.

U.N Doc. S/PV.1441 (1968) (Situation on Czech).

U.N Doc. S/PV.2185 (1980) (Situation on Afg).

U.N Doc. S/PV.746 (1956) (Situation on Hung).

U.S. Constitution. Preamble.

UN General Assembly (1948). Universal Declaration of Human Rights. UN General Assembly, 302.

UN High-Level Panel (2004). Para 188.

UNSC News (2013). Jordan Elected to Serve on UN Security Council. https://news.un.org/en/story/2013/12/457222

UNSC News (2015). Egypt, Japan, Senegal, Ukraine and Uruguay Elected to Serve on UN Security Council.

https://news.un.org/en/story/2015/10/512712-egypt-japan-senegal-ukraine-and-urugua y-elected-serve-un-security-council

UNSC. https://www.un.org/securitycouncil/content/kuwait

Vertin, Z. (2019). Red Sea Rivalries: The Gulf, the Horn, and the New Geopolitics of the Red Sea. Washington DC: Brookings Institute.

W Michael Reisman, Ibid, at 869.

Weller, M. (2010). Iraq and the Use of Force in International Law. Oxford: Oxford University Press. https://doi.org/10.1093/acprof:oso/9780199595303.001.0001

Werr, P. (2013). UAE Offers Egypt \$3 Billion Support, Saudis \$5 Billion. World News, July 9, 2013.

https://www.reuters.com/article/us-egypt-protests-loan/uae-offers-egypt-3-billion-sup port-saudis-5-billion-idUSBRE9680H020130709

Westra, J. (2007). International Law and the Use of Armed Force: The UN Charter and the Major Powers. London: Routledge.

Wilmshurst, E. (2006). The Chatham House Principles of International Law on the Use of Force in Self-Defense. International \& Comparative Law Quarterly, 55, 963-972. https://doi.org/10.1093/iclq/lei137

Wippman, D. (1996a). Defending Democracy through Foreign Intervention. Houston Journal of International Law, 19, 659.

Wippman, D. (1996b). Military Intervention, Regional Organisations, and Host-State Consent. Duke Journal of Comparative \& International Law, 7, 209-240.

World Health Organisation (2020). Who Coronavirus Disease (COVID-19) Dashboard. 
https://covid19.who.int

World News (2015). Air Strike on Missile Base in Yemen Capital Kills 25, Wounds Hundreds. Routers.

https://www.reuters.com/article/us-yemen-security/air-strike-on-missile-base-in-yeme n-capital-kills-25-wounds-hundreds-idUSKBN0NB0R820150421

Xu, M. Y., \& Chen, A. Z. (2020). China Oil Imports from Top Supplier Saudi Arabia Rise 47\% in 2019: Customs. Reuters, January 31.

https://www.reuters.com/article/us-china-economy-trade-oil/china-oil-imports-from-t op-supplier-saudi-arabia-rise-47-in-2019-customs-idUSKBN1ZU0EH

Yoo, J. (2004). Using Force. The University of Chicago Law Review, 71, Article 1.

Yoo, J. C., \& Trachman, W. (2004). Less than Bargained for: The Use of Force and the Declining Relevance of the United Nations. Chicago Journal of International Law, 5, 379-394. 